\title{
Mitigating drudgery of farm women through technology intervention in rural Punjab
}

\author{
GURUPDESH KAUR AND RACHNA SINGLA* \\ Krishi Vigyan Kendra, PATIALA(PUNJAB) INDIA
}

\begin{abstract}
With growing concerns and realization on the need for empowering women in agriculture, focus has been on developing core competencies in the area of general issues in agriculture, skill development of stake holders and inclusion of women perspective as in-built component in agricultural research. Keeping these points in mind the present investigation was planned to mitigate drudgery of farm women in agricultural operations. The study was conducted in villages of 3 districts namely Patiala, Barnala and Sangrur of Punjab State. A sample of 90 farm women in the age group of 20-45 years who were involved in various agricultural operations were selected for this study. A self structured and pre-tested interview schedule was used to collect data. Field investigations were also made to observe the farm activities of women. The results revealed that participation of farm women was higher in activities like grain storage, manual harvesting, picking of vegetables and animal dung collection and its disposal. Awareness level of participants regarding drudgery reduction tools was very low before trainings. After trainings, female labourers had 78.2 per cent gain in drudgery reduction techniques.
\end{abstract}

KEY WoRds : Rural women, Agriculture, Farm activities, Drudgery reduction tools, Technology intervention

View Point Article : Kaur, Gurupdesh and Singla, Rachna (2017). Mitigating drudgery of farm women through technology intervention in rural Punjab. Internat. J. Home Sci. Extn. \& Comm. Manage., 4 (1): 43-47. DOI : 10.15740/HAS/IJHSECM/ 4.1/43-47.

Article History : Received : 27.09.2016; Revised : 03.12.2016; Accepted : 19.12.2016

\footnotetext{
* Author for correspondence : Email : singlarachna77@gmail.com
} 